\title{
Thermal and Economic Study of a Combined Power and Cooling Cycle
}

\author{
Mohamad Mehyo ${ }^{1,2} \mathbb{B}^{\circ}$, Hakan Özcan ${ }^{2}$ \\ Department of Mechanical Engineering, Ondokuz Mayis University, Körfez Mahallesi, 19 Mayıs Ünv. Kurupelit Kampüsü, 55105 Atakum, Samsun, Turkey
}

\begin{abstract}
An energy crisis has become a global problem which restricts the sustainable growth recently. For this reason, waste heat recovery from different thermal systems has become so important. There are many ways to utilize the waste heat, and absorption refrigeration systems are one of the best ways to use waste energy. On the other hand, Power plants are at the forefront of industries where energy consumption is most intense. For this reason, improving the performance of these plants will save energy, water, as well as contribute to the prevention of environmental risks. In this study, a new and a suitable absorption refrigeration system was proposed for recovering the waste heat from drainage tanks in AL-Zara steam plant in Hama in Syria. In addition, thermal and economic analyses were applied to study the feasibility assessment of using waste heat based on the measured data from Al-Zara steam power plant. The absorption refrigertaion cycle of the drainage tank waterworks by Ammonia-Sodium Thiocyanate as a working solution, which achieves the highest coefficient of performance at available thermal conditions where reaches to (0.49). The profitability for three cooling units reaches to (37206 $€)$, comparing to similar compression cooling cycle in the same capacity.
\end{abstract}

Keywords: Steam Power Plant, Waste Heat, Drainage Tank, Absorption Refrigeration System.

\section{INTRODUCTION}

The current energy generation and utilization patterns can directly lead to considerable wasted energy either at medium or high availabilities. For example, power plants utilize the high-grade portion of fossil-derived energy and reject a large amount of medium-grade thermal energy [34].

Refrigeration systems are generally compression systems driven by electrical power. On the other hand, absorption system is an alternative approach; which uses thermal power (industrial waste heat, renewable energy sources, or other thermal sources) as driving energy. Furthermore, ARSs do not cause ozone depletion, with natural substances, as working solutions [1-4]. Numerous researchers have studied various ARSs using different thermal energy sources. Dincer and Ratlamwala [35] highlighted the recent developments and potential applications in the area of absorption refrigeration systems. This chapter provides an overview of the studies carried out concerning advanced multigeneration systems, novel ARS mixtures and novel ARS designs. Al-Ugla et al. [5] have built $24 \mathrm{~h}$ solar power absorption system in Saudi Arabi. In this study alternative designs for solar-powered $\mathrm{LiBr}-\mathrm{H}_{2} \mathrm{O}$ absorption air conditioning systems are tested. Three designs (heat storage, cold storage, and ref- rigerant storage) are investigated. Khaliq et al. [6] have suggested cogeneration cycle, a $\mathrm{LiBr}-\mathrm{H}_{2} \mathrm{O}$ ARS is utilized the combined power and ejector refrigeration cycles which uses R141b as a working solution. Assessment for irreversibilities of individual components of the cycle leads to possible measures for performance enhancement. Vidala et al. [7] have proposed a new combined cycle by performing an exergy analysis method. This cycle by using $\mathrm{NH}_{3}-\mathrm{H}_{2} \mathrm{O}$ mixture produced both power and cooling simultaneously from one heat source. Khaliq et al. [8] studied a tri-generation system depending on a gas turbine cycle and recovering the heat for a steam generator and an ARS. First and second law concepts were used with computational analysis to study effects of overall parameters of the cycle (pressure ratio, turbine inlet temperature, the pressure drop in combustor and heat recovery steam generator, and evaporation temperature) on the exergy in every component.

An $\mathrm{NH}_{3}-\mathrm{H}_{2} \mathrm{O}$ ARS was built and studied by Sierra et al. [9]. By using a heating temperature of less than $80^{\circ} \mathrm{C}$. The system has reached a cold temperature less than $-2^{\circ} \mathrm{C}$. But, the achieved $C O P$ of this system was at a range between 0.240.28 . Several small capacity systems with an $\mathrm{NH}_{3}-\mathrm{H}_{2} \mathrm{O}$ were also studied empirically [10-13]. These systems were ope- 
rated based on surrounding temperatures and solar collectors with a heating temperature not less than $80^{\circ} \mathrm{C}$ and not more than $200^{\circ} \mathrm{C}$. The achieved $C O P$ of these systems was at a range between 0.12 and 0.50 at temperatures between -18 to $10^{\circ} \mathrm{C}$. Either high efficient flat plate solar collectors or vacuum tube collectors were utilized in these systems as a heating source.

To perform the air condition system with low-temperature heat sources, a lot of systems were proposed and studied with $\mathrm{H}_{2} \mathrm{O}-\mathrm{LiBr}$ as a working solution $[14,15]$. These systems were examined based on the cooling $\mathrm{H}_{2} \mathrm{O}$ temperatures with a heating $\mathrm{H}_{2} \mathrm{O}$ temperature between 75 and $95^{\circ} \mathrm{C}$. consequences of operating present that the produced cold temperature is between 12 and 16 and the achieved COPs are between 0.60 and 0.75 .

Academic investigations of the thermodynamic modeling of ARSs with several working solutions have been obtained by a lot of researchers [16-19]. Most of these investigations were achieved with satisfactory results. Pilatowsky et al. [20] have used monomethylamine- $\mathrm{H}_{2} \mathrm{O}$ as a working solution in their investigations at low temperatures between $60-80^{\circ} \mathrm{C}$. They got good results in general and low $C O P$. It was achieved a cold temperature between -5 to $10^{\circ} \mathrm{C}$ and $C O P$ from 0.05 to 0.55 . Lucas et al. [21] have discussed ( $\mathrm{LiBr}: \mathrm{CHO}_{2} \mathrm{~K}$ $=2: 1)$ as an absorbent instead of just $\mathrm{LiBr}$ for the refrigerant $\mathrm{H}_{2} \mathrm{O}$ to decrease the required temperature. By using a simulation method, the thermal parameters of the system were calculated with this new working solution. The result which was obtained has shown that the system can generate a cold temperature of $6{ }^{\circ} \mathrm{C}$ with a $C O P=0.85$ at a temperature of $56^{\circ} \mathrm{C}$. But, the absorption temperature must be low at $15^{\circ} \mathrm{C}$ and this degree is not allowed in boundary conditions so this temperature should be obtained by some another cooling source.

A lot of ideas were performed for the benefit of solar and waste thermal energy to run up a double-stage ARS [22-25]. It can be realized that these double-stage systems have higher $C O P$ than single-stage ones, but there are disadvantages, such as high costs and required driving temperatures. Although several studies of different types of these systems for cooling purposes were an important research topic; however, this subject still requires further research regarding the uninterrupted supply of cooling effect using solar energy [26]. The necessary continuity is provided by the drainage tanks at the plant in this study.

\section{METHODS AND AIMS}

This study was conducted at AL-ZARA Thermal Power Plant in Hama Province in Syria. The study lasted for a year. Three generating units, which constitute the plant, were observed and the all necessary data for the study was obtained daily and throughout the year. The waste heat sources were identified, such as temperatures and flows, which were read depending on loads of plant throughout the day.
The study aims to:

1- Identifying the properties of the waste heat source (drainage tanks) in AL-ZARA Plant and benefit from them from thermal and technical aspects.

2- Determining optimum operating conditions for working the ARSs with this source by studying the thermal properties of working solutions and choosing the right one.

3- Fulfilling the economical and thermal study in order to invest this energy and know its impact on the refrigeration operation.

\section{FUNDAMENTALS AND DESIGN ASSUMPTIONS OF AL-ZARA THERMAL POWER PLANT}

Al-Zara Thermal Power Plant Syria is located at the West of AL-Rastan, Syria. Location coordinates are: Latitude= 34.959, Longitude $=36.661$. This plant is of TYPE Oil power plant with a design capacity of $660 \mathrm{MWe}$. It has 3 units. The first unit was commissioned in 2000 and the last in 2001. It is operated by Al-Zara Power Public [27]. The study was conducted by data of the three generating units of 2010 .

Table 1 Fundamentals and design assumptions of AL-ZARA Plant [27].

\begin{tabular}{|l|l|}
\hline Fundamental assumptions & Plant standards \\
\hline $\begin{array}{l}\text { Environment conditions of the surroun- } \\
\text { ding }\end{array}$ & $19.5^{\circ} \mathrm{C}, 65 \% \mathrm{RH}, \mathrm{U}_{\mathrm{w}}=10-15 \mathrm{~m} / \mathrm{s}$ \\
\hline Surrounding conditions in peak periods & $40^{\circ} \mathrm{C}, 50 \% \mathrm{RH}, \mathrm{U}_{\mathrm{w}}=20-25 \mathrm{~m} / \mathrm{s}$ \\
\hline Design temperature & $26^{\circ} \mathrm{C}$ \\
\hline Load of the plant & $660 \mathrm{MW}$ \\
\hline $\begin{array}{l}\text { Design temperature of the cooling water } \\
\text { at the entrance of the cooling tower }\end{array}$ & $50^{\circ} \mathrm{C}$ \\
\hline $\begin{array}{l}\text { Design temperature of the cooling water } \\
\text { at the outlet of the cooling tower }\end{array}$ & $40.2^{\circ} \mathrm{C}$ \\
\hline $\begin{array}{l}\text { Design thermal consumption with a } \\
\text { median load }\end{array}$ & $2139 \mathrm{kcal} / \mathrm{kW}-\mathrm{h}$ \\
\hline
\end{tabular}

\section{PROPOSED SYSTEM DESCRIPTION}

\subsection{Main drainage tanks}

The drainage water which comes from different components of the plant and from assistance equipment is collected in this tank. This water has different temperatures and pressures depending on its source. On the other hand, the average temperature of all drainage water in this tank is almost up to $90^{\circ} \mathrm{C}$ and it is constant during the normal work of each unit throughout the day. But its flow varies depending on the load of the sets [27]. The flow rate value is approximately equal $90 \%$ of the compensation water that is added to the thermal cycle for each generating set. Following is flow values of drainage water which comes out of the drainage tank for the second unit in a normal workday of September 2010, the values of flow throughout the day are shown in Fig. 1.

It can be noted from Fig. 1 direct proportion between the water drainage flow rate and the load of the generating set throughout the day. And noting that in some cases as a result of chemical analysis of drum water and when these tests indicate to an increase in the proportion of impurities and dissolved salts in the water scavenging, It is increased the 
slot of scavenging valve for a limited period until the ratios of these impurities returning to the normal value.

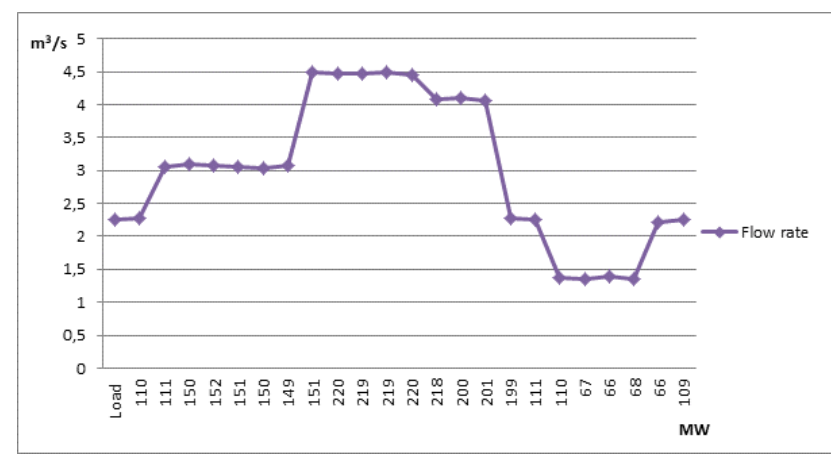

Figure 1. The drainage water flow rate depending upon the load of the generating set throughout the day

\subsection{Proposed ARS description}

\subsubsection{System description}

Fig. 2 shows a single-stage of ARC. The main components of the single-stage absorption system are: condenser, evaporator, absorber, pumps, heat exchangers and the generator. The ARS operates in two pressure levels while in operation [33]. The high-pressure in the cycle is the condenser pressure and the generator pressure, while the evaporator pressure is the low-pressure and the absorber pressure. The pump raises the pressure of the working solution from the low-pressure to the high-pressure. The solution is heated to by waste heat in order to separate the refrigerant, then going to the condenser. The refrigerant pressure is reduced by the expansion valve before entering the evaporator. The evaporation of refrigerant extracts heat $\mathrm{Q}_{\mathrm{E}}$ from the evaporator providing refrigeration effect [33].The cooling effect occurs at the low pressure. In the absorber, the refrigerant is absorbed into the poor working solution which is returning from the generator (after reducing the pressure by the expansion valve), and it is produced heat as a result of the absorption process, which requires cooling the absorber [28].

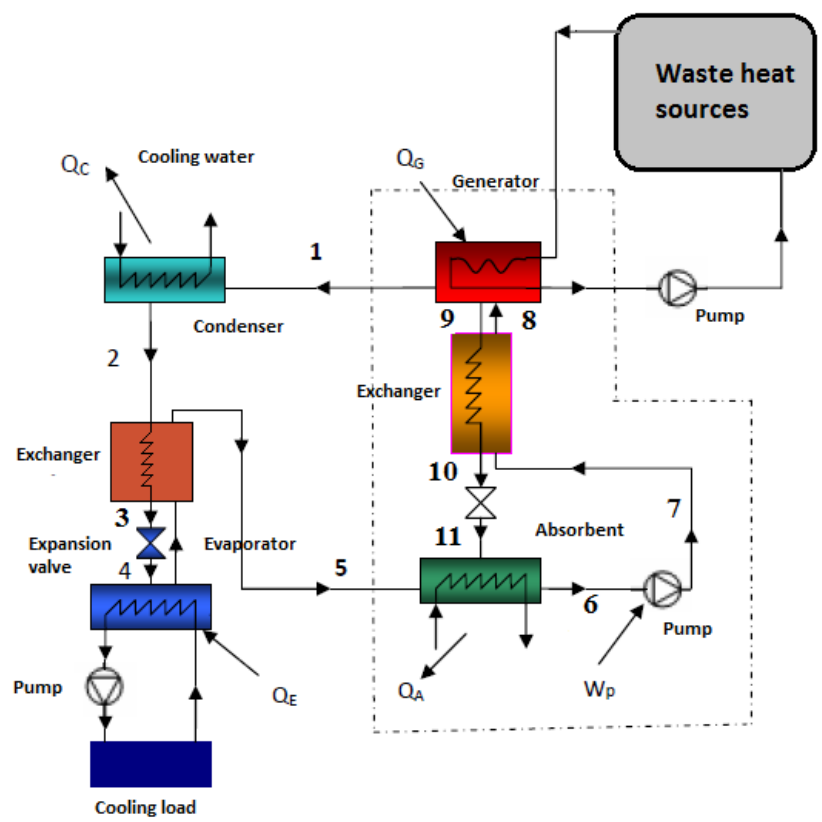

Figure 2. Schema of a simple system of ARC runs by the waste heat
It is clear from the above explanation that the operation of ARC needs heat to be added to the generator instead of the work which is necessary for the compressor in the event of using the compression refrigeration cycle. The work value of the used pump is too small compared with the amount of heat which is added to the generator, so it can be neglected. COP is defined as follows:

$$
C O P=\frac{\dot{Q}_{E}}{\dot{Q}_{G}+W_{P}}
$$

Equation (1) is calculated from the thermodynamic cycle analysis [14]:

The circulation coefficient $(f)$ is defined as the ratio of the amount of the solution which goes out from the absorber to the amount of vapor which enters the condenser.

$$
f=\frac{\dot{m}_{7}}{\dot{m}_{1}}\left(\frac{k g_{\text {sol }}}{k g_{\text {ref }}}\right)
$$

By neglecting the pump's work, $C O P$ becomes:

$$
C O P=\frac{\dot{Q}_{E}}{\dot{Q}_{G}}
$$

When the cycle works as a heat pump, the $\varepsilon_{e d}$ becomes:

$$
\varepsilon_{a d}=\frac{\dot{Q}_{C}+\dot{Q}_{A}}{\dot{Q}_{G}}=\frac{\dot{Q}_{K}}{\dot{Q}_{G}}
$$

Depending on the energy conservation law, the capacity coefficient of the absorption heat pump is bigger in one than COP of absorption cycle which works in the same work conditions:

$$
\varepsilon_{\text {ed }}=C O P+1
$$

\subsubsection{Working solutions characteristics}

It is mentioned several binary working solutions which will probably be benefited from one of them to study their impact on the effectiveness of a single-stage ARS to choose the appropriate one, depending on the temperature of the waste heat sources [9]:

1. $\mathrm{H}_{2} \mathrm{O}-\mathrm{LiBr}: \mathrm{H}_{2} \mathrm{O}$ is the refrigerant and $\mathrm{LiBr}$ is the absorbent.

2. $\mathrm{NH}_{3}-\mathrm{H}_{2} \mathrm{O}: \mathrm{NH}_{3}$ is the refrigerant and $\mathrm{H}_{2} \mathrm{O}$ is the absorbent.

3. $\mathrm{NH}_{3}-\mathrm{NaSCN}: \mathrm{NH}_{3}$ is the refrigerant and $\mathrm{NaSCN}$ is the absorbent.

4. Acetone- $\mathrm{ZnBr}_{2}$ : Acetone is a refrigerant and $\mathrm{ZnBr}_{2}$ is the absorbent. It is worth mentioning that the Acetone$\mathrm{ZnBr}_{2}$ solution is a new working solution.

Thermal properties of refrigerant (pressure, temperature, concentration, enthalpy, and density) are necessary in order to the mathematical modeling of ARSs. Since these thermal properties are used from the outlet of the generator to the entrance of the absorber and rest parts of the cycle are used thermal properties of the solution $[14,29]$. 
From literature, Ajib and Karno [30] have studied and by using the EES program (Engineering Equation Solver), in different work conditions the COP of absorption cycle. The program solved experimental relations of thermal properties of solutions which mentioned above. Then a comparison was done between studied working solutions.

In order to use the available sources in the plant in the best way, and determine the optimal operation of ARSs, it was benefited from the comparison between solutions after dividing them into two groups and with different thermal conditions for every group depending on the possible thermal average that can be worked at it, as follows [28]:

1. The first group: $\mathrm{H}_{2} \mathrm{O}-\mathrm{LiBr}$ and Acetone- $\mathrm{ZnBr}_{2}$ which only work at a $t_{E}$ higher than $\left(0^{\circ} \mathrm{C}\right)$ (air-conditioning applications), and it has been studied at following thermal conditions: $t_{\mathrm{E}}=+5{ }^{\circ} \mathrm{C}, t_{\mathrm{C}}=+30^{\circ} \mathrm{C}$, $t_{\mathrm{G}}=+65^{\circ} \mathrm{C}$.

2. The second group: $\mathrm{NH}_{3}-\mathrm{H}_{2} \mathrm{O}$ and $\mathrm{NH}_{3}-\mathrm{NaScN}$ which work at a $t_{\mathrm{E}}$ higher and lower than $\left(0^{\circ} \mathrm{C}\right)(\mathrm{su}-$ itable for both refrigeration and air-conditioning applications), and it has been studied at following thermal conditions: $t_{\mathrm{E}}=-5^{\circ} \mathrm{C}, \mathrm{t}_{\mathrm{C}}=+30^{\circ} \mathrm{C}, \mathrm{t}_{\mathrm{G}}=+90$ ${ }^{\circ} \mathrm{C}$.

As it is shown in Fig. 3, the various values of COP of ARSs are depending on the $t_{G}$ by using the $\mathrm{H}_{2} \mathrm{O}-\mathrm{LiBr}$, Acetone- $\mathrm{Z}$ $\mathrm{nBr}_{2}$ at $t_{E}=+5{ }^{\circ} \mathrm{C}, t_{C}=+30^{\circ} \mathrm{C}$, and the $\mathrm{NH}_{3}-\mathrm{H}_{2} \mathrm{O}, \mathrm{NH}_{3}-\mathrm{NaS}$ $\mathrm{CN}$ at $t_{E}=-5^{\circ} \mathrm{C}, t_{C}=+30^{\circ} \mathrm{C}$.

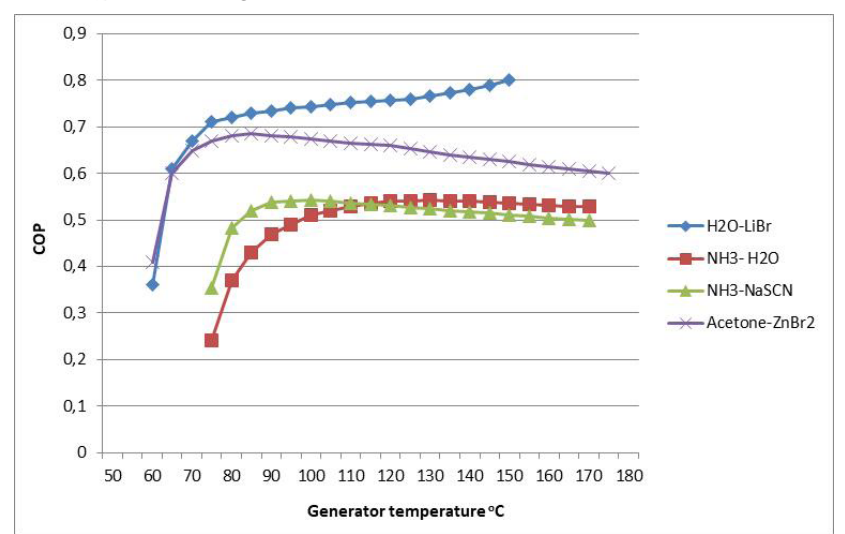

Figure 3. COP values of compared solutions related to the $t_{G}[28]$.

Fig. 3 shows, for the first group, that COP of the cycle with Acetone- $\mathrm{ZnBr}_{2}$ as a working solution reaches to the greatest value at a $t_{G}$ almost equal $80^{\circ} \mathrm{C}$, and then it begins to decrease due to the behavior of the solution depending on the thermodynamic properties in this average. When it is used the $\mathrm{H}_{2} \mathrm{O}$ - $\mathrm{LiBr}, C O P$ values remain increasing as long as the $t_{G}$ increases. It is also noted that $C O P$ values of the Acetone- $\mathrm{ZnBr}_{2}$ cycle are higher than the $\mathrm{H}_{2} \mathrm{O}-\mathrm{LiBr}$ cycle in peak periods and after that, the $\mathrm{COP}$ values of the $\mathrm{H}_{2} \mathrm{O}-\mathrm{LiBr}$ cycle become higher. For the second group, COP of the $\mathrm{NH}_{3}-\mathrm{NaS}$ $\mathrm{cN}$ cycle increases until it reaches the greatest value at a $t_{G}$ equal to approximately $95^{\circ} \mathrm{C}$ and then begins to decrease. COP of $\mathrm{NH}_{3}-\mathrm{H}_{2} \mathrm{O}$ cycle increases by increasing the generator temperature, and $C O P$ values of the $\mathrm{NH}_{3}-\mathrm{NaScN}$ cycle higher than the $\mathrm{NH}_{3}-\mathrm{H}_{2} \mathrm{O}$ one until $120^{\circ} \mathrm{C}$, after that $\mathrm{COP}$ of the $\mathrm{NH}_{3}-\mathrm{H}_{2} \mathrm{O}$ becomes higher.

Fig. 4 shows a comparison between circulation coefficients of different solutions depending on the mentioned generator temperatures at the same previous boundary conditions $t_{C}, t_{E^{\prime}}$ each according to the group which it belongs. For the first group, $f$ of the $\mathrm{H}_{2} \mathrm{O}$ - $\mathrm{LiBr}$ cycle is lower than the Acetone- $\mathrm{ZnBr}_{2}$ cycle. The $f$ of the $\mathrm{NH}_{3}-\mathrm{H}_{2} \mathrm{O}$ cycle is lower than the $\mathrm{NH}_{3}-\mathrm{NaScN}$ one, and the difference between $f$ values decreases with the increasing of generator temperature.

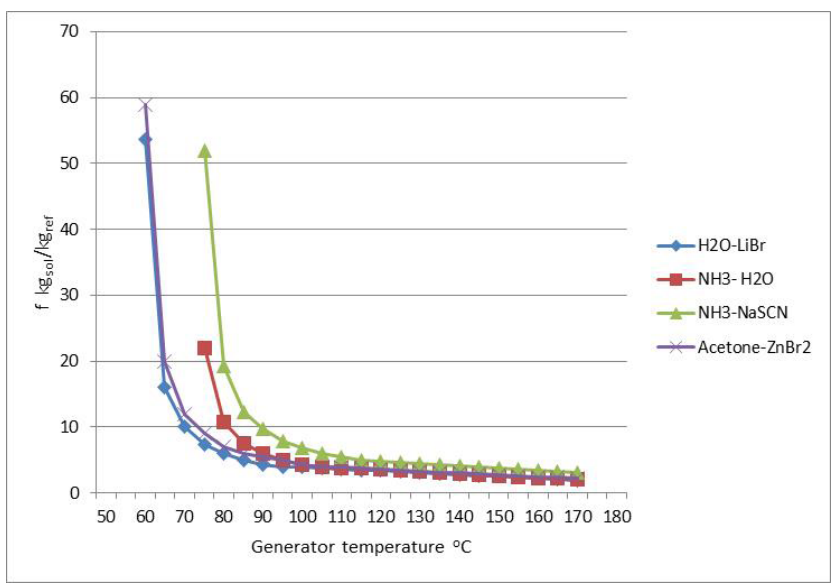

Figure 4. $f$ values of compared solutions related to the $t_{G}$ [28].

\subsubsection{Economic calculations (prices and mathematical models)}

Annual costs of the system are calculated by the following prices and equations [31]:

1- The electricity price is: $248(€ / \mathrm{y})+0.1426(€ / \mathrm{kW}-\mathrm{h})$ [31].

2- The natural gas price is: $0.0403(€ / \mathrm{kW}-\mathrm{h})+3.2(€ /$ $\mathrm{kW}$ y) [31].

3- The cooling water price is: $1.89(€ / \mathrm{kW}-\mathrm{h})+245(€ /$ y) [31].

4- The price of the consumed water is: $2.15(€ / \mathrm{kW}-\mathrm{h})+$ $73.7(€ / y)[31]$.

$$
\begin{aligned}
& K_{\text {ges }}=K_{o}+K_{l} \\
& K_{o}=\frac{K_{i n v} \times q^{n}(q-1)}{q^{n}-1}
\end{aligned}
$$

Where: $q=0.6$ The interest of the capital investment, $n$ using time.

Operating costs:

$$
K_{1}=K_{1 h w}+K_{1 k w}+K_{1 e l}+K_{1 i n s}
$$

- The annual cost of the operation and the investment time for studied cooling units are given in the Table A2.

- Investment time (recovery of capital) is calculated by the following equation [31]:

$$
A_{z}=\frac{K_{i n v, s o l}-K_{i n v, r e f}}{\left(K_{1 e l}+K_{1 k w}\right)-\left(K_{1 e l}+K_{1 k w}+K_{1 h w}\right)}
$$




\section{RESULTS AND DISCUSSION}

This system consists of three cooling units (one for each electric generating unit), each of them has an ARS which is run by the waste heat of the drainage tanks or other energy resources, and the working solution in the cycle is $\mathrm{NH}_{3}-\mathrm{NaS}$ $\mathrm{CN}$.

The cooling capacity and other data per unit are given in Table A2.

- Work hours: 2000 work hours during the year.

- The coverage ratio from the waste heat of the drainage tanks 0\%, 20\%, 40\%, 60\%, 80\%, 100\% respectively.

- The boundary conditions for each unit are same.

- The cooling capacity: $90 \mathrm{~kW}$.

- The evaporator temperature: $-5^{\circ} \mathrm{C}$.

- The condenser temperature: $80^{\circ} \mathrm{C}$.

- The second heat source is burning natural gas [31],[32].

The absorption cycle curves were obtained when the system works with $\mathrm{NH}_{3}-\mathrm{NaScN}$ and at different work conditions that follow water drainage tank specifications for the second unit in one day in September of 2010. The measured parameter is the flow of the drainage tank water $\dot{m} \mathrm{~kg} / \mathrm{s}$, and calculated ones are capacities and coefficients $C O P, \varepsilon_{e d d^{\prime}}$ The drainage water temperature remains constant throughout the normal work day of the generating unit and it is roughly equal to $90^{\circ} \mathrm{C}$.

This value is not relate to the surrounding temperature, but the flow is variable depending on the value of the generating unit load. With this value and if we assume that all the heat exchange processes occur with temperature difference $\Delta t=10^{\circ} \mathrm{C}$ the moderation temperature of the absorption system generator is approximately equal $t_{G}=80{ }^{\circ} \mathrm{C}$, and depending on this value and from experimental relationships of thermal properties of $\mathrm{NH}_{3}-\mathrm{NaScN}$, equations of refrigerant $\mathrm{NH}_{3}$ and Fig. 3, coefficients of this system is equal to $C O P=0.49, \varepsilon_{e d}=1.49$. Capacities and coefficients of the ARS which works by the thermal energy of drainage tank water at working conditions in one day in September of 2010 are described as follows:

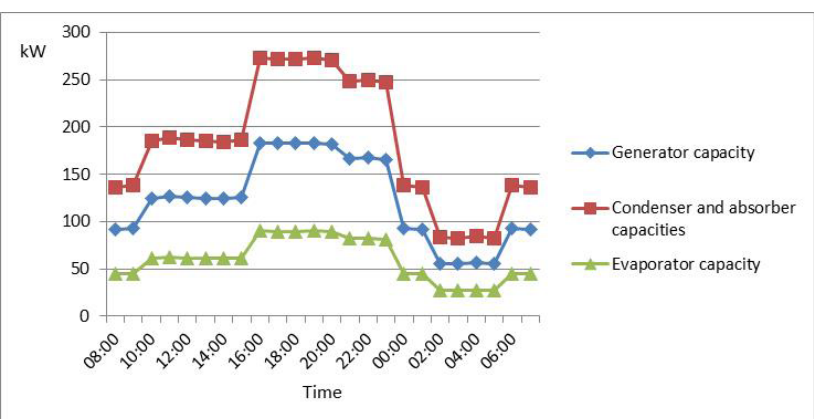

Figure 5. Evaporator capacity, generator capacity, condenser capacity and absorber capacity values throughout the day, according to the flow of drainage water.
In Fig. 5, the changes in the three capacities are commensurate with the drainage water flow. These changes throughout the day even though it was large in some periods, they do not affect the continuity of the work of the absorption system due to the availability of generation capacity on a clock, and the thermal inertia of the ARS alleviates the impact of these changes.

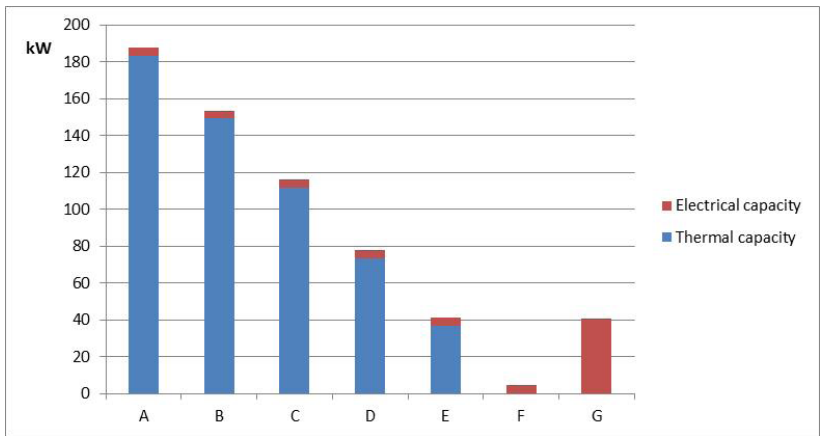

Figure 6. Heating capacity depending on the coverage of the energy sources

It can be noted from Fig. 6 that the electricity consumption of the absorption system is generally less than $12 \%$ of the electricity consumption of the compared compression refrigeration system. It is also noted that the possibility of securing the necessary heat energy to the system depending solely on drainage water heat.

It is noted from Fig. 7 that annual operating costs of ARSs get close to annual operating costs of the compared system (compression) when the system works by direct gas burning with $100 \%$. Operating cost of the ARS decrease when it is only depending on the drainage water heat. Where savings in operating costs reach up to $54 \%$ (12402 $€$ / y for each refrigeration unit) when the total reliance is on the energy of the drainage water heat.

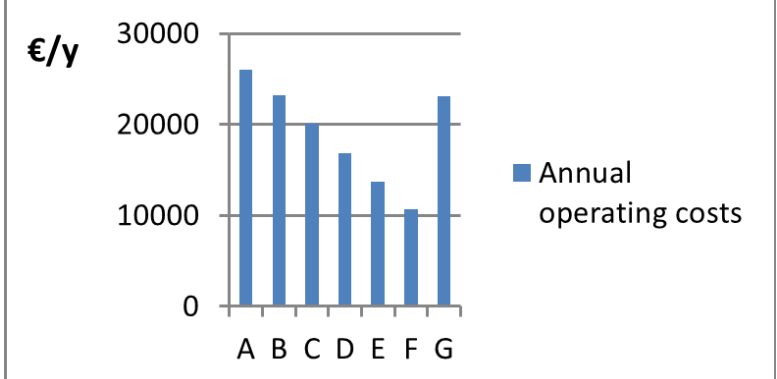

Figure 7. Annual operating costs depending on the coverage of the energy sources.

\section{CONCLUSION}

The study gave an idea about the ARS working curves at different working conditions and different capacities. Where the generator of the ARS is run by the waste heat of drainage tanks. Also, the comparison between two grubs of working solutions was allowed us to choose the working solution which is suitable for the available heating temperature in the cycle which was studied. On the other hand, the economic and thermal results show the following resultes:

1. The ARS of the drainage tank water works by 
$\mathrm{NH}_{3}-\mathrm{NaScN}$, which achieves the highest COP at the available thermal conditions, where reaches to (0.49).

2. The profitability of the absorption cycle for three refrigeration units reaches to $(37206 €)$, compared with the ordinary compression refrigeration cycle that is similar it in the capacity.

\section{Acknowledgment}

This work was supported by AL-ZARA Electrical Power Generator Company. We would like to thanks all of the company's staff for their supporting throughout the data collection period.

\section{Appendix A}

Table A2. Annual operating costs for the cooling sets which works by the waste energy of the drainage tank water according to methods of operation and heat supplying system in order to operate 2000 hours/year

\begin{tabular}{|c|c|c|c|c|c|c|c|}
\hline \multirow{2}{*}{ Technical data } & \multicolumn{6}{|c|}{ Absorption system } & \multirow{2}{*}{$\begin{array}{c}\text { Comp- } \\
\text { ression } \\
\text { system } \\
\text { G }\end{array}$} \\
\hline & A & B & C & $\mathrm{D}$ & $\mathrm{E}$ & $\mathrm{F}$ & \\
\hline Cooling capacity (kW) & 90 & 90 & 90 & 90 & 90 & 90 & 90 \\
\hline $\begin{array}{l}\text { Heating capacity of the } \\
\text { natural gas }(\mathrm{kW})\end{array}$ & 183.6 & 149.3 & 112 & 73.5 & 36.7 & - & - \\
\hline $\begin{array}{l}\text { Required electrical capa- } \\
\text { city }(\mathrm{kW})\end{array}$ & 4.46 & 4.46 & 4.46 & 4.46 & 4.46 & 4.46 & 40.5 \\
\hline $\begin{array}{l}\text { The amount of a new } \\
\text { water }\left(\mathrm{m}^{3} / \mathrm{y}\right)\end{array}$ & 1134 & 1134 & 1134 & 1134 & 1134 & 1134 & 837 \\
\hline $\begin{array}{l}\text { The consumed amount of } \\
\text { water }\left(\mathrm{m}^{3} / \mathrm{y}\right)\end{array}$ & 281 & 281 & 281 & 281 & 281 & 281 & 210 \\
\hline $\begin{array}{l}\text { Costs of the heating energy } \\
(€ / y)\end{array}$ & 15385 & 512511 & 9453 & 6159 & 3075 & - & - \\
\hline $\begin{array}{l}\text { Costs of the electrical } \\
\text { energy }(€ / y)\end{array}$ & 1520 & 1520 & 1520 & 1520 & 1520 & 1520 & 11798 \\
\hline $\begin{array}{l}\text { Costs of the cold water } \\
(€ / y)\end{array}$ & 2388 & 2388 & 2388 & 2388 & 2388 & 2388 & 1826 \\
\hline The capital $(€)$ & 62803 & 362803 & 62803 & 62803 & 62803 & 362803 & 60440 \\
\hline $\begin{array}{l}\text { The expectancy life for } \\
\text { every unit }(y)\end{array}$ & 20 & 20 & 20 & 20 & 20 & 20 & 10 \\
\hline Annual capital costs $(€ / y)$ & 5476 & 5476 & 5476 & 5476 & 5476 & 5476 & 8209 \\
\hline $\begin{array}{l}\text { Annual maintenance costs } \\
(€ / y)\end{array}$ & 1255 & 1255 & 1255 & 1255 & 1255 & 1255 & 1208 \\
\hline $\begin{array}{l}\text { Annual operating costs } \\
(€ / y)\end{array}$ & 26024 & 423150 & 20092 & 16798 & 313714 & 40639 & 23041 \\
\hline $\begin{array}{l}\text { The capital recovery time } \\
(y)\left(A_{z}\right)\end{array}$ & - & - & 8.98 & 0.66 & 0.35 & 0.24 & - \\
\hline \multicolumn{8}{|c|}{ A: Operating by burning the natural gas directly. } \\
\hline \multicolumn{8}{|c|}{$\begin{array}{l}\text { B: Operating by burning the natural gas } 80 \% \text {, and } 20 \% \text { from the condens- } \\
\text { er cooling water energy. }\end{array}$} \\
\hline \multicolumn{8}{|c|}{$\begin{array}{l}\text { C: Operating by burning the natural gas } 60 \% \text {, and } 40 \% \text { from the condens- } \\
\text { er cooling water energy. }\end{array}$} \\
\hline \multicolumn{8}{|c|}{$\begin{array}{l}\text { D: Operating by burning the natural gas } 40 \% \text {, and } 60 \% \text { from the condens- } \\
\text { er cooling water energy. }\end{array}$} \\
\hline \multicolumn{8}{|c|}{$\begin{array}{l}\text { E: Operating by burning the natural gas 20\%, and } 80 \% \text { from the } \\
\text { condenser cooling water energy. }\end{array}$} \\
\hline \multicolumn{8}{|c|}{ F: Operating by the condenser cooling water energy. } \\
\hline \multicolumn{8}{|c|}{$\begin{array}{l}\text { G: Operating by only the compared system (compression sys- } \\
\text { tem). }\end{array}$} \\
\hline
\end{tabular}

\section{REFERENCES}

[1] Kaynakli O. and Kilic M. (2007). Theoretical study on the effect of operating conditions on performance of absorption refrigeration system. Energy Conversion and Management, 48(2): 599-607.

[2] Saravanan R. and Maiya M. P. (1998). Thermodynamic comparison of water-based working fluid combinations for a vapour absorption refrigeration system. Applied Thermal Engineering, 18(7): 553-568.

[3] Sozen A., (2001) "Effect of heat exchangers on performance of absorption refrigeration systems," (in English), Energy conversion and management., vol. 42, no. 14, pp. 1699-1716, 2001.

[4] Sun D.-W. (1998). Comparison of the performances of $\mathrm{NH} 3-\mathrm{H} 2 \mathrm{O}$, $\mathrm{NH}$ 3-LiNO 3 and $\mathrm{NH}$ 3-NaSCN absorption refrigeration systems. Energy Conversion and Management, 39(5): 357-368.

[5] Al-Ugla, A. A., El-Shaarawi, M. A. I., \& Said, S. A. M. (2015). Alternative designs for a 24-hours operating solar-powered LiBr-water absorption air-conditioning technology. International Journal of Refrigeration, 53: 90-100.

[6] Khaliq, A., Agrawal, B. K., \& Kumar, R. (2012). First and second law investigation of waste heat based combined power and ejector-absorption refrigeration cycle. International Journal of Refrigeration, 35(1): 88-97.

[7] Vidal, A., Best, R., Rivero, R., \& Cervantes, J. (2006). Analysis of a combined power and refrigeration cycle by the exergy method. Energy, 31(15): 3401-3414.

[8] Khaliq, A. (2009). Exergy analysis of gas turbine trigeneration system for combined production of power heat and refrigeration. International Journal of Refrigeration, 32(3): 534-545.

[9] Sierra, F. Z., Best, R., \& Holland, F. A. (1993). Experiments on an absorption refrigeration system powered by a solar pond. Heat Recovery Systems and CHP, 13(5): 401-408.

[10] Ajib, S., \& Schultheis, P. (1998). Untersuchungsergebnisse einer solarthermisch betriebenen Absorptionskälteanlage. TAB. Technik am Bau, (2): 49-54.

[11] Jakob U., Schneider D., Eicker U., and Bauingenieurwesen B., (2004) "Entwicklung einer Diffusions -Absorptionskältemaschine kleiner Leistung (2, 5 kW)," in Band Drittes Symposium Solares Kühlen in der Praxis, HfT Stuttgart, 2004, pp. 26-27.

[12] Kunze, G. (2000). Efficient solar cooling with an improved ammonia-absorption system. Renewable Energy World, 3(6), 111-112.

[13] Safarik, M., Gramlich, K., \& Schammler, G. (2002, June). Betriebserfahrungen der solar angetriebenen $15 \mathrm{~kW} \mathrm{NH3/H2O-Absorptions-}$ kä Iteanlage am Technologiezentrum Kothen. In Tagungsband Zweites Symposium-Solares Kuhlen in der Praxis, Vero ffentlichungen der Fachhochschule Stuttgart-Hochschule fu r Technik (Vol. 56, pp. 145-175).

[14] Xiaohong, L. (2004). The development of an air-cooled absorption chiller concept and its integration in CHP systems (Doctoral dissertation, Dissertation University of Maryland, College Park).

[15] Schweigler, C., Costa, A., Högenauer-Lego, M., Harm, M., \& Ziegler, F. (2002, June). Entwicklung und Betrieb einer 10 kW H2O/LiBr-Absorptionskältemaschine. In Tagungsband: Zweites Symposium „Solares Kühlen in der Praxis ", Stuttgart (p. 110ff).

[16] Alizadeh, S., Bahar, F., \& Geoola, F. (1979). Design and optimisation of an absorption refrigeration system operated by solar energy. Solar Energy, 22(2), 149-154.

[17] Chen, G., \& Hihara, E. (1999). A new absorption refrigeration cycle using solar energy. Solar Energy, 66(6), 479-482. 
[18] Wang, J., Chen, G., \& Jiang, H. (1998). Study on a solar-driven ejection absorption refrigeration cycle. International journal of energy research, 22(8): 733-739.

[19] Wijeysundera, N. E. (1997). Thermodynamic performance of solar-powered ideal absorption cycles. Solar energy, 61(5): 313-319.

[20] Pilatowsky, I., Rivera, W., \& Romero, R. J. (2001). Thermodynamic analysis of monomethylamine-water solutions in a single-stage solar absorption refrigeration cycle at low generator temperatures. Solar energy materials and solar cells, 70(3): 287-300.

[21] De Lucas, A., Donate, M., Molero, C., Villaseñor, J., \& Rodrıguez, J. F. (2004). Performance evaluation and simulation of a new absorbent for an absorption refrigeration system. International Journal of Refrigeration, 27(4): 324-330.

[22] Wijeysundera, N. E. (2000). An irreversible-thermodynamic model for solar-powered absorption cooling systems. Solar Energy, 68(1): 69-75.

[23] Alizadeh, S. (2000). Multi-pressure absorption cycles in solar refrigeration:: A technical and economical study. Solar energy, 69(1): 37-44.

[24] Schweigler, C. (2004, April). Solare Klimatisierung mit zweistufigem Absorptionskälteanlage. In Band Drittes Symposium Solares Kuhlen in der Praxis (pp. 211-229).

[25] Lokurlu, A., \& Richarts, F. (2002, June). Zweistufige Absorptionskältemaschine mit Parabolrinnenkollektoren. In Band Zweites Symposium Solares Kühlen in der Praxis (pp. 98-109).

[26] Said, S. A., El-Shaarawi, M. A., \& Siddiqui, M. U. (2012). Alternative designs for a 24-h operating solar-powered absorption refrigeration technology. International journal of refrigeration, 35(7): 1967-1977.

[27] ---(2010). The archive and records of the AL-ZARA Thermal Power Plant

[28] El-Sayed, M. M., Fathy, A. K., \& Mogahed, S. A. (1998). Computational Models of Solar Thermal Systems. Center for Scientific Publishing King Abdulaziz University, Jeddah, 808.
[29] Reid, R. C., Prausnitz, J. M., \& Poling, B. E. (1987). The Properties of Gases and Liquids, McGraw-Hill. New York, 136.

[30] Ajib, S., \& Karno, A. (2008). Thermo physical properties of acetone-zinc bromide for using in a low temperature driven absorption refrigeration machine. Heat and mass transfer, 45(1): 61-70.

[31] Al-Masri R. et al. (2008). Reference in the principles of solar thermal applications. Al - Baath University.

[32] Ebade S. T. et al. (1998). Fundamentals of Finance and Financial Management. Ain Shams Library, Cairo.

[33] Singh, K. P., \& Singh, O. (2019). Thermodynamic Investigation of Solar Energy-Driven Diffusion Absorption Refrigeration Cycle. In Advances in Fluid and Thermal Engineering (pp. 459-478). Springer, Singapore.

[34] J. Li, X. Kong. (2018). Thermally Activated Refrigeration Technologies. Handbook of Energy Systems in Green Buildings, 655-712, Springer-Verlag GmbH Germany, part of Springer Nature 2018.

[35] Dincer, I., \& Ratlamwala, T. A. H. (2016). Developments in Absorption Refrigeration Systems. In Integrated Absorption Refrigeration Systems (pp. 241-257). Springer, Cham.

\begin{tabular}{|ll}
\hline \multicolumn{2}{l}{ Nomenclature } \\
$C O P$ & coefficient of performance \\
$f$ & circulation coefficient \\
$\varepsilon_{e d}$ & effectiveness of the thermal system \\
$\mathrm{U}_{\mathrm{w}}$ & wind speed, $\mathrm{m} / \mathrm{s}$ \\
$Q_{G}$ & generator capacity, $\mathrm{kW}$ \\
$Q_{A}$ & absorber capacity, $\mathrm{kW}$ \\
$Q_{C}$ & condenser capacity, $\mathrm{kW}$ \\
$Q_{E}$ & cooling capacity, $\mathrm{kW}$ \\
$W_{P}$ & pump working, $\mathrm{kW}$ \\
$t_{E}$ & evaporator temperature, ${ }^{\circ} \mathrm{C}$ \\
$t_{G}$ & generator temperature, ${ }^{\circ} \mathrm{C}$ \\
$t_{C}$ & condenser temperature, ${ }^{\circ} \mathrm{C}$ \\
$K_{o}$ & capital costs, $€$ \\
$K_{l}$ & operating costs, $(€ / \mathrm{y})$ \\
$K_{i n v}$ & capital investment, $€$ \\
$K_{l h w}$ & heating costs (hot water - gas - electric energy), \\
& (€/y)
\end{tabular}

$K_{l k w} \quad$ cold water costs, $(€ / \mathrm{y})$

$K_{\text {lel }} \quad$ costs of the electrical energy, $(€ / \mathrm{y})$

$K_{\text {lins }}$ maintenance costs $=2 \%$ of capital investment costs, $(€ / y)$

A $\quad$ investment time, $\mathrm{y}$

$K_{i n v, r e f}^{z}$ capital investment in the compared system (com pression), $€$

$K_{\text {inv,ref }} \quad$ capital investment when the system is operated by the waste heat, $€$

$\begin{array}{ll}\mathrm{ZnBr}_{2} & \text { Zinc Bromide } \\ \mathrm{LiBr} & \text { Lithium Bromide } \\ \mathrm{H}_{2} \mathrm{O} & \text { Water } \\ \mathrm{NH}_{3} & \text { Ammonia } \\ \mathrm{NaScN} & \text { Sodium Thiocyanate }\end{array}$

\section{Subscripts}

ARS absorption refrigeration system

ARC absorption refrigeration cycle 